\title{
THE RE-DISCOVERY OF PHILORUS (BLEPHAROCERA) YOSEMITE OSTEN SACKEN.
}

BY VERNON L. KELLOGG, STANFORD UNIVERSITY, CAL.

About 3 P. M. on June 6, I876, Baron von Osten Sacken caught three flying male Blepharocerid flies "on the bridle-path to the foot of the Upper Yosemite Fall." From these specimens he described the new species Blepharocera yosemite, and since that time no further records of the capture of representatives of the species have been made. This last summer, while tramping and climbing in the Sierra Nevadas, I took occasion to visit the "bridle-path to the foot of the Upper Yosemite Fall" with Osten Sacken's twenty-five years gone capture in mind, but there were no delicate-winged $B$. yosemite hovering by the path side. About sixtymiles farther south, however, in another great Californian flat-floored, vertical walled gorge, the Grand Canyon of the King's River, I found the larvae and pupae of a Blepharocerid species new to me, which prove, on dissection of the well formed adults from the pupal cases, to be the immature stages of Osten Sacken's Yosemite species. I have before me males and females (taken from the pupal cases), larvae and pupae, so another gap in our knowledge of the Blepharocerid fauna is filled in.

These larvae and pupae were taken July $\mathbf{1}_{5}$, 1903, from the smooth, submerged surfaces of great granite blocks fallen into a swift little clear-water stream called Granite Creek, from a vertical cliff-side lifting three thousand feet above. In the relation of their home stream to the great mountains, in all their environment, they might as well have been in the Yosemite Valley in the stream which falls 1600 feet over a cliff's verge to make the Upper Yosemite Fall. The two great canyons, that of the Merced (the Yosemite) and that of the King's, have the same relative relation to the main crest of the Sierra Nevada, the same altitude, the same conditions of temperature and moisture, the same geology and botany and zoology.

The imagines (dissected from pupal cases) show exactly the characteristic venation as described by Osten Sacken, which I have taken to be diagnostic of the genus Philorus (see my "Net-winged Midges of North America," No. XXX of Contrib. to biol. from the Hopkins seaside laboratory, 1903).

As Osten Sacken had no female specimen and thus could not say whether the separated and dissected eyes of the male were characteristic of both sexes I record here the fact that in the female the eyes are broadly separated and also distinctly bisected (that is, divided by a line into an upper, light brown part, being about $\frac{}{5}$ of the whole eye, composed of large ommatidia, and a lower, blackish brown part composed of smaller ommatidia). 
The pupae differ from those of all other Blepharocerid species known to me in having the dorsal prothoracic respiratory flaps contiguous ; they are distinctly apart in all other known pupae. The larvae more nearly resemble those of Bibiocephala comstocki Kell. (a species common in the Santa Cruz Mountains of the San Francisco peninsula) than those of any other species, having the lateral processes in much the same condition. They differ noticeably, however, in being much darker and without spots on the dorsum.

I add, in closing this note, two records of Blepharocerid distribution which are not included in my monograph of February (referred to above). Professor Cockerell has taken Bibiocephala grandis in New Mexico, and Professor Aldrich Bibiocephala elegantulus in Idaho.

Two Coccids from Samoa.- While in the Samoan Islands during the summer of 1902 (on the Samoan Explorations expedition of the U, S. bureau of fisheries) I collected two well-known species of scale insects which I note are not recorded in Mrs. Fernald's catalogue from these islands. These two Coccids are Coccus (Lecanium) hesperidum, found abundantly at Apia (Upolu island) on oranges (the orange in the South Seas has its ripe fruit green in color and very small); and Hemichionaspis aspidistrae found on the "ti" plant, Cordyline terminalis, at Pago-Pago (Tutuila Island). The "ti " is that widely distributed native plant of the Pacific Islands whose leaves will be remembered by visitors to Honolulu as the attractive fresh green wrapping "paper" used by the dealers in the great fish market.Vernon L. Kellogg.

Amory Leland Babcock, born Nov. I5, 1826, died Feb. 27, 1903, at Sherborn, Mass. Mr. Babcock was throughout a long and active life an enthusiastic collector of natural history specimens, devoting his energies chiefly to forming an extensive private collection of animals and curios from every quarter of the globe. Attracted strongly by the beauty of birds and butterflies he directed his energies chiefly to these groups, especially in his earlier years. Accompanied by his wife he spent several months in the winter of $1872-3$ in British Guiana, collecting in the vicinity of Georgetown and among the Indian villages of the interior along the Essequibo river. The winter of $\mathrm{I} 879-80$ was spent in a similar trip to Florida.

During later years he had devoted his time chiefly to insects and by collecting and exchanges had secured a large amount of material. Of the local fauna he had paid most attention in these later years to the Odonata, and several collections are the richer for his efforts in this direction. "Enallagma pictum was described from material in his collection and the types were donated by him to the Museum of comparative zoölogy.

Mr. Babcock, while hampered exceedingly by lack of means and early advantages, possessed energy, enthusiasm, and perseverance to a notable degree, and a lover of nature was always sure of his interest and encouragement. It is to be hoped that his collection may remain intact as a fitting monument to his untiring efforts and singleness of aim.Albert P. Morse. 

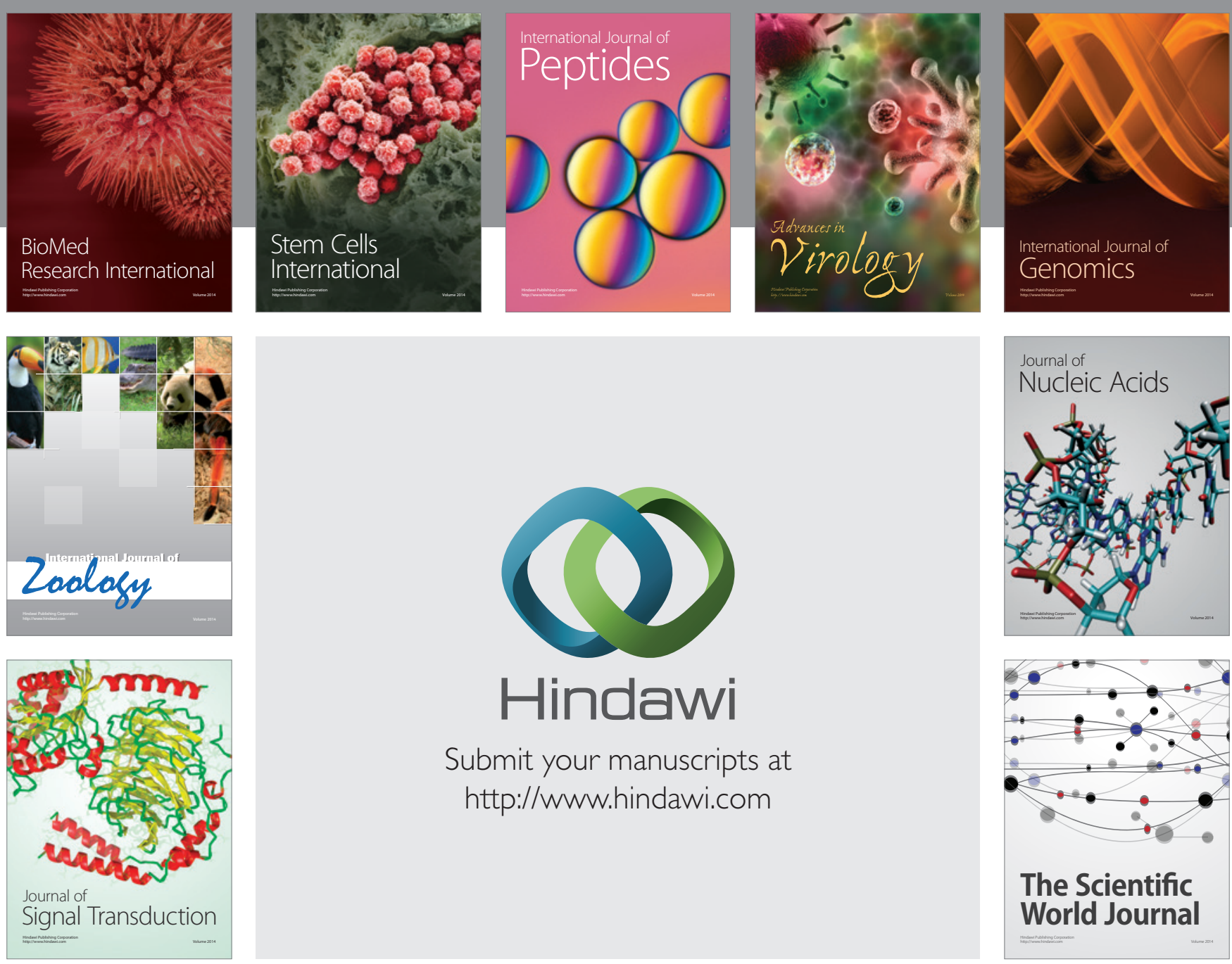

Submit your manuscripts at

http://www.hindawi.com
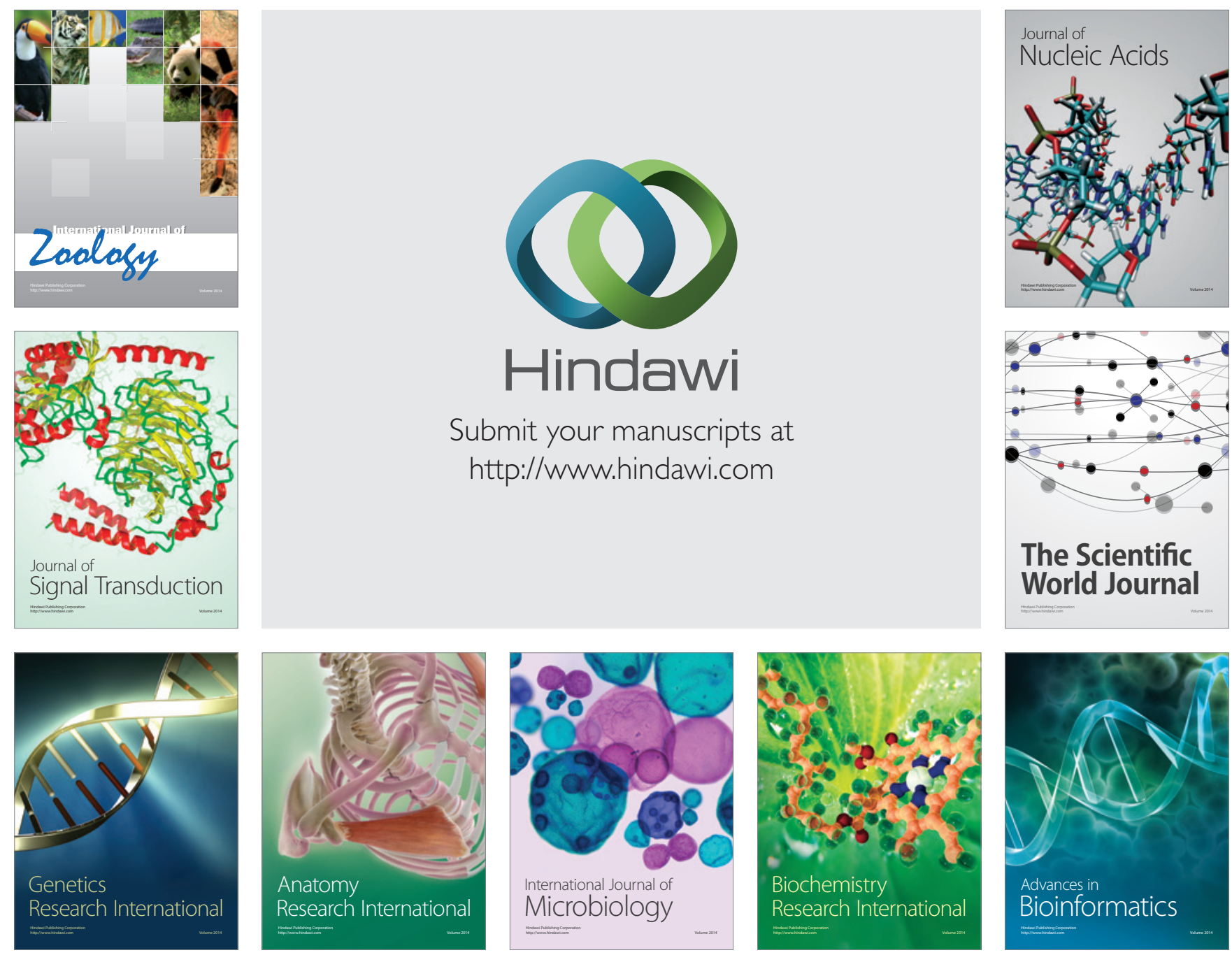

The Scientific World Journal
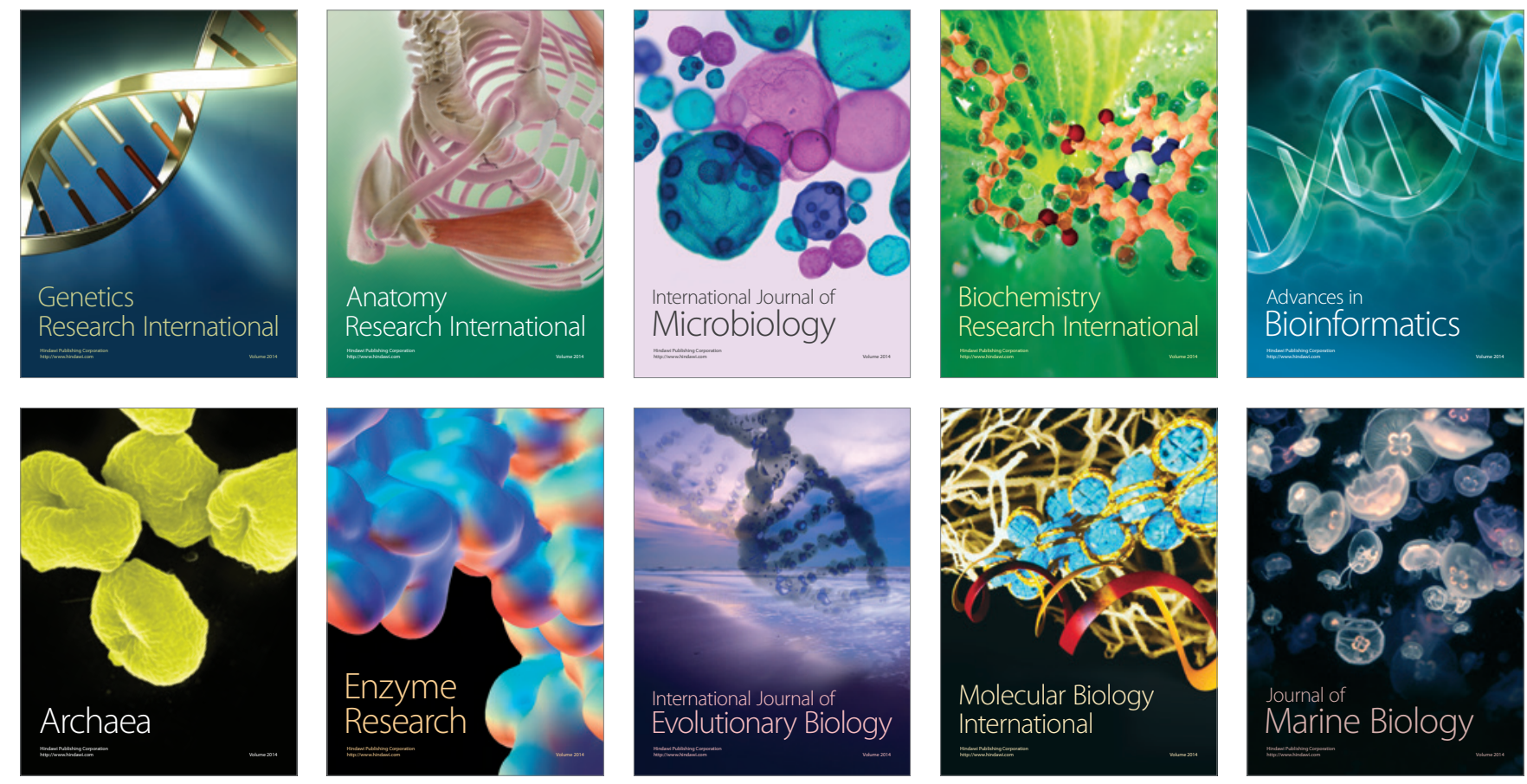